\title{
THE BALKANS TODAY: The EU and the Region
}

\section{Dimitrios Triantaphyllou*}

\section{Abstract}

The challenges that face the Balkans today are relatively benign compared to those that confronted the region a decade ago. Regional cooperation is ongoing and the democratic process is taking hold. Nevertheless, the region's transition is not yet complete and there is a compelling need for further efforts. Especially when America's gradual retreat from Europe is taken into consideration, the need for the EU to manage this transition is evident. In this regard, it can be said that the Balkans present the principal testing ground of the EU's CFSP and the ESDP. This paper tries to focus on some of the challenges that face the region and offers ways for the international community; particularly the EU, to deal with them effectively.

The Balkans are a two edged challenge for the European Union. On the one hand, they represent Europe's backyard and therefore, the need for Europe to manage them is imperative; on the other hand, the Balkans are the principal testing ground of Europe's CFSP and evolving ESDP. Simultaneously, for the states of the Balkans, the EU represents the only viable option if the region is to escape its recent past and its retarded development. In other words, the stakes are high for all parties concerned. The successful symbiosis between the European Union and the Balkans will assure that the region's challenges will be met if realistic policy options where both the EU and the region come out on top are implemented.

Defining the context, both regional and international, in assessing the Balkans today is important if one is to have a clear and balanced evaluation of developments in the region. A number of givens exist on the ground and in terms of action by the international community towards the region. At the

\footnotetext{
* Senior Research Fellow, European Union Institute for Security Studies
} 
same time, mony unknow wathles aro also present. It is the retationship between lacts ant challenges that shape the Batkans present and futus direction.

\section{What are the facts?}

1. The vertebtal colum of peace in the Batkans comes in the form of three intemutional accords - he Dayton accords that put an end to the war in bosnia in 1995; the Ramboullet regentanens and UNSCR 1244 that deremined the future of Kowoug in 199\%, and the Ohrid Agreement of aystst 2001 tha pul an end to intercthric

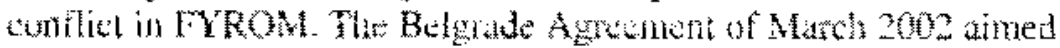
at defining the transformation of FR Yutewistute into Serbia and Montencegro can also be considered part of the region's arehitecture though its viability is still untertain.

2. Also, three fators that contributed to ar fudled violente for over a decade have been renoved. These ure:

* The crat of nationalist trablenakers in Conatia and Serbia has onne to an end. Not only have these leaders gone but their politen intratructure has been crumbling as well.

- Tlie potental for further violent disintegration appears to be centainable in that by early 2002 , no state or spinter nation in the Butkans was in a pusition to engage in any prolonged wathere.

- The divixims between the Europeans and the US over policy in the region have lartrely evaporated!

As a consequence, one can say that there ars atavely fow problem in the Balkans today. These include the abeston of Kosovo's that stutus; deuling with war criminati and the fight against oramised trime. None are insumountable given proper attention although their potential for destabilisution of the region is great and merits close montaring

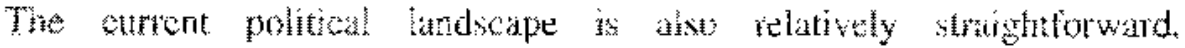
Enlargement is on the agenda forr ati Balkan states though it is more evitent far sorne that othets. The conclusions of the Copenhagen Eumpear

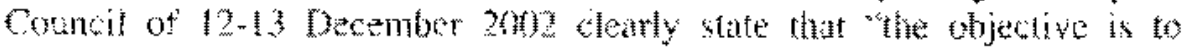
welcome Bugaria and Romanir as members of the European Union in

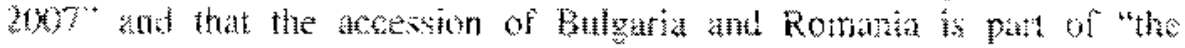


inclusive and ireversible entargement process" of the Union. ${ }^{2}$ For the oher Bakan countries, the Copenhagen European Council "reafinms the Eumpean perspective of the counmes of the Westem Dalkans in the 5 tabilisation and Association Proces5... and underlines its determination to support their efforts to move closer to the $\mathrm{LI}^{\mathrm{I}^{* 3}}$ The Greek Presidency of the EU during the ftrst half of 2003 plans to organise a Summit on 21 June between EU Member States and comatries of the Stabilisation and Association Process to reinforce this point. The ltalian presidency that is to follow assures continuty with the Greze Presidency with regatd to a focus on bue Balkans over the whole of 2003 .

The year 2003 also brings with it somen new challenges that will or could have an impact on the Balkans. The wrst has to to with gradual US

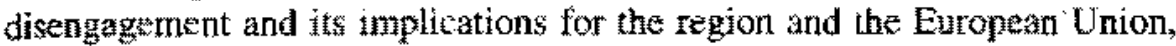
which wll have to sep up its efforts and presence diplomaticalyy and militarily as the real powertomker in the region. Secondly, entargement could sidemack the EU as it whl begin looking inwards to integrate its newcomers rather than address its new peripheries the let guts in the case of the Balkans). Thirly, the anti-immigration mod in Europe as reflected in many pols in many EU member siates might reinforce the sentiment shared by many Serbs and Albanans that they arto not welcomed. Finally; the cultivation of partition agendots beth within and outside the region cond be potentially destabilising. The latest example comes after the Bosnia pols of September 2002 , interpreted by many (especially in the West) as the failure of Dayton and the need to radically revise it.

\section{The mid to long term challenges}

Oyer the longer term, the challenges therafore ane manageable given careful planning; apporopriate commitment and poltical will. Five major chattenges stand out, in particular for the European Union as at attempts to integrate the region. These include:

1. Addressing the unmosolved status issues, in particular Kosovo's status and the Albanian question on factor, which cmanates from the fact that Kosovo's firnal status is still unresolyed.

2. Managing the Eutopean perspextre for the regron is another major challenge. There is a disconnection between the perspective of accession and ins distant reality. That to to say, the prospect of EU membership is a very enticing "carrot" but it is also quite distant. 
3. Related to the above, coping with the heterogeneity of the region both in terms of relations with the European Union and NATO is crucial.

4. The European Union contributing more eflectively to addrcssing the crucial problems of the region and, thereby maintaining Balkan stability (in particular, in the Western Balkans).

5. Finally. diminishing resources as the post-conflict international missions to reconstruct and stahilise the Balkans are drawing to a close, the international community's lacking attention span due to the absence of serious ethnic conflict and the gradual but certain US disengagement need to be assessed by the countries of the region and the European Lnion in order to avoid any unpleasant surprises in the future.

\section{An assessment of recent developments}

Nevertheless, there are clear signs that trouble could be brewing if developments and challenges are not carefully assessed and no appropriate responses both by the international community and the states of the region are implemented. The results of the South East Europe Public Agenda Survey released on 2I March 2002 are telling. Across the region the three issues most consistently identified by the survey as causes of public concern are unemployment, corruption and crine. ${ }^{+}$The recent elections in the region in the fall of 2002 are indicative of these concerns. While with this round of elections, we had for the first time free and fair elections across the region; the protest vote is growing. It is governing the political process in the Balkans. The refornist momentum has suffered a serious setback as the reformists do not have a strong and well-articulated public majority and no genuine new reform leader has emerged. An anti-elite vote is growing across the region. I will particularly focus on the case study of the Bosnian clections to illustrate their implication on Bosnia's and the region's immediate future while Kosovo will not be dealt with, as its recent electoral evolution has been relatively calmer than that of its neighbours.

\section{- Bosnia-Herzegovina ${ }^{5}$}

The 5 October 2002 elections in Bosnia-Herzegovina demonstrate how divided the intemational community is with regard to the viability of that 
country and the continued implementation of the Dayton Accords. The

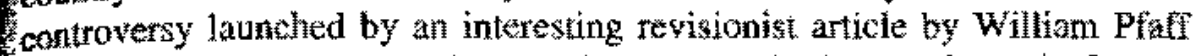
westarted for the umptemth tirne the debate over the luture of Bosnia. Yet all

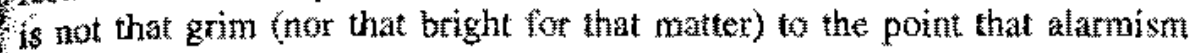
should warry the day.

A frot rogding of the election results (together with the resuls of the Serbian elections) could suggest the perseverance of ethnic and political divisions to the detriment of more "pro western" raform candidates but appearanes can be deceiving. The elsetion campaign was anlke previous campangns in that it was not marred by violense. Also, unlike the four proceding elections held since 1996, thes were the first elections ofganised exclusively by the Bosnians (with discrext assistance from the international community, of course). As for the election results, Javier Solanta, the European Union's Security Chief, put it best when he said that these tections "represent a vote of frustration" and "the expression of disappointment at the lack of change, not a vote for the past". Lukewise, Paddy Kshdown, the intarnational community' head honcho in BosniaHerzegoving stressed that the result was a protest vots or "a protest nonvote" against the reformess that uad bexn in power over the last two years rather than "at return to the nationalism of 10 yeass ago"

Are Solana and Ashtown putting on to bave face in the midst of a deteriorating poltical and ethric situation? The low turnout $(55,54 \%)$ and the weak participation on the part of intellectuats, youth, and certain segments of the refugees and intemally displaced persons might have contributed to the victory at the nationatsit parties. With 40 percent. umemployment, an averaze monthly salary of $150-200$ enros, growida povery, perststent fratd and torrupton, the discontent of those wanting mon reforms was cetaly felt, As a consequence, sectarian voting benefited. Other factors inculute the mixed record of the international community on the issue of refugee returns for example, Republika Srpskat is amost exclusively Serb today whereas before the war approximately the same number of Serbs, Croats and Bosniaks jow there) and ts inatility to arrest Radoyan Karadzic and Racko Mladic. The two aforementioned factors also had a say in justifying the preference for national homogeneities arrong the viters.

This, of course, comes about at a time when the country is in the midst of uncerain economic reforms, decreaseng intemational aid, and latgenting foreign investment. On the plus side, the country no longer poses a threat to 
its neighbours, the concept atd pretios of "ownersho" of the pontical and economic process fas taken hold, as bos the pocess of regional cooperation. Also the canangign focts was on concerns ouer the economy, the nationalist. parties have moved awiay from some of thein mote debatable leaders and positons, and sone ethic diwesity has terppeared (some refugee resurns. afer all, are better than none, Amidst this binesweet really, where do we go from here?

Two camps stand ont. The frst suggests that the Dayton canctuct camot

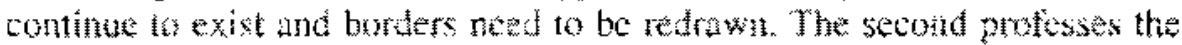
need to stay the course alteit by doing more. Whim Ptalf"s "Time 10

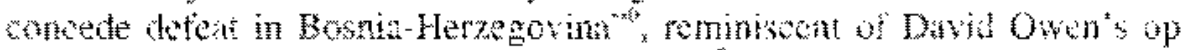

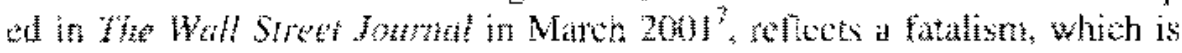
not without logk and a dose of ralism. Aconding ro Ptiff, the ume has come for the intemationat community to cede defeat and acknowledge that Besnia Herzegovina "has for all practical purposes, already beta ethnically cleased, and atepting the consejtences, now may be the only wy to teminate this part of the problem of Yugeslav subession." As a result, the partition of Bosna anow is necessary if democratic walues ma benter

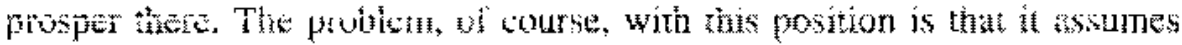
that this is what the citizens of Bownia want througt a cursory assessmont of the election restles and without considefing the regional itrplications. A redruwing of borders could finally bring to thition the mach tebated and dreaded domino effect with Kosoyars pressing fur mmediate independence and the ethnic groups in Macedonia optize for pitrition.

On the ther hand, preserving Bosnia as is a nonstarter. The existing dysfunctionat poltical system and government stucture maintains the country s ethnic divsion. How to make the system more wokathle at a time when the internarional community, too proccupied with fraty, is mointerested and internationat assistance is declining places the onus on Faddy Aslowewn and his tean in Satateve. The ditemna is how to reinfore the presene of the intemational communty in tems of providmg idea and gutdelines for urent conomis seloms lest parts of the country topple into crise withour anecting miraces woh as the arrest of Katadzic and Mladio anytime som

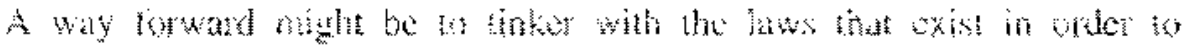
untermine the nutionilise parties. For examples the devolution of powar to

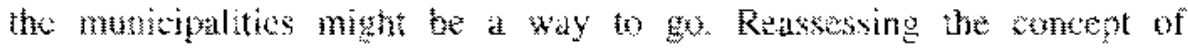
"ownership" by ving it to a stutegy of condmonuly (whereby exth 
transfer of power to the locals could be linked to gaining their consensus for cach possible legal atteration could be another option. Needtess to say, the constant recalibration of the strategic plan is a must.

The fact that the international military presence has been considerably downsized attests to the growing stability in the country. It also proves that cyen with lessening resources much is possible. While the American factor ruighi become less relevant over time as the United States gradually disengages, the European Union's influence and interest is bound to grow as is first crisis management operation under ESDP is underway in BosniaHerzegovina starting since 1 January 2003 in the form of the EUPM (EU Police Mission), This development not only show a commitment to rule of law reform in Bosnia on the part of the EU but also continued and sustained Interest in assuring that peace implementation and stabilisation succeed in Bosnia-Herzegovina. That is to say, the stakes for success of its crisis management operation are so high for the EU that it cannot afford to fail. As a conseguence, it will have no choice but to work closely with the Bosnian authorities and the High Representative thereby assuring that political and cononic reforms do not go off-track.

In other words, the Bosnian elections have proven to be a wake up call to how much still needs to be done in the country. There are enough tell tale signs, though, from the local political forces and the international commurity that they are aware of the stakes and the ned to wak together. The nation-building experiment will stay on course notwithstanding required alterations because no other credible altemative can replace it.

\section{- FYR Macedonia}

The country is still fragile even after the 15 September parliamentary elections, whot were the first since the brokering of the Ohria ranawork Agreenent of August 2001. While democratic procedures were respected during the voling process (no fraud, no major incidents, no major escalation of thne conflict), corruption is still prevalent and the participation of Ali Ammeti, the former KLA leader in the political process is still questioned by many \$lawoMacedonians. As a consequence the confidence of the public in public institutions (such as the parliament, the government and local authoritisy is relatively low ${ }^{z}$ Given that a real redistribution of power on the Albanian side the DPA's stranglehold on political and regional powst) has yet to occur, it is still too early to suggest that stability and prosperity will come anytime soon in the country. The fortheoming announcement of 
last November's census results could lead to strategic bovcotts by the Albanian parties to dispute the results if they are not to their liking. The Presidential elections in 2 years will be crucial as it is possible that hard-line nationalist SlavoMacedonian candidates could probably put partition on the electoral agenda.

\section{- Serbia}

Two fiileul rounds of presidential elections in Serbia 29 September and 8 December) could jeopardise its political instilutions and bring the reform process to a halt. The personilication of the political conlirontation between two of Milosevic's potitical heirs, Vojislar Kostunicit and Zoran Djindjic, is not a good omen. The reform monnentum has been lost, as the young and urban population did not vote and the reformers have split. The pro-western constitucncy is limited to a third of the population. The altemative to reforms is nationalist leadership personitied by Vojislav Seselj who managed a million votes in the last election doing well in regions such as Vojvodina. This could imply that the disintegration of the country is not yet over. Unless legislative reforms that "clarify the mandates of the political institutions, regulate the inter-institutional exchanges, optimise the internal institutional proccdures and rationalise the lection rules" are introduced, Serbia's institutions will not be able to withstand further political manipulations. ${ }^{14 t}$ Given that no bloc in the Serbian parliament can count on a stable majority, the deadlock of the reform process is bound to continue at the expense of Serbia's stability.

\section{- Montenegro}

While the 20 October parliamentary elections brought an absolute majority for the Democratic List for a European Movement of President Djukanovic, his decision to switch jobs to the premiership made the speaker of parliament the frontrunner in the presidential poll of 22 December. As in the case of Serbia, a boycott of the elections by Djukanovic's focs led to the invalidation of the elections due to low voter turnout. The impact is largely economic given "the prospect of at least one and probably two more elections, which are likely to make a severe dent in the meagre budget of this impoverished Balkan nation." "Yet one cannot help wonder of the impact of the electoral deadlocks both in Serbia and Montenegro on the negotiations on the constitutional charter of the new state of Serbia and Montenegro. As late as mid-January 2003, a number of points remain unresolved as well, including legislation on implementing the document and 
the mechanism for electing teputiss to the joint parliament as well as how to reframe retations with intemational financial instictutions.

\section{- Albania}

Albania has been relatively quiet throughout 2002 given the EU-enformed cooperation agreernent between the ruling socialszts and the main opposition Democratic Party some ime in the spring. The deal was reached "after prolonged EU pussure on Albania to clean up its act as a condition for beginning negotiations for entry into a stabilisation and Association Agreament, SAA." "The alection of Aufred Moisiv to the presictency in June 2002 was the most visible outcome of this deal as the mandate given to the

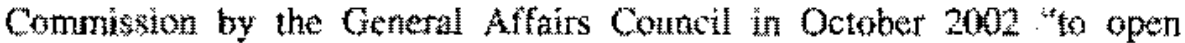
nezotiations on a Stabilisation and Assoctation Agreement with Abania." How long the deal will stand is debateble given the defeat of a Democtatis Pary candidate in parhamentary by-olection in December 2002 latang Sall Derisha, the opposition leader to actuse ane Socialisis of fonl play. ${ }^{14}$

\section{Lstes to address}

Consenuently, a number of questions staming from the series of challenges, develogments, and policy options presented throughout ihis paper, need to be constidered. The list of guestions that follows is not xhaustive but it is indicative of those that need to be posed as policy is being formulated for the Balkans of tomorrow.

\section{- Do we need to think in terms of an exit strategy?}

There is a necessity to address the ousis of political remesentation and to avert a miture of depentency. This might imply more involvement in the short tam based on the prospect of an exit strategy over the long term. ${ }^{15}$ More involvement implies a more hands on approach by the European union, NATO and the OSCE in dismantling lawless power structures and institutionalising the rute dit law across the region. ${ }^{\text {if }}$

- Is the International community an obstacle as it refuses to address status issues? 


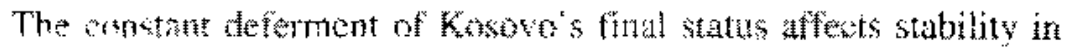

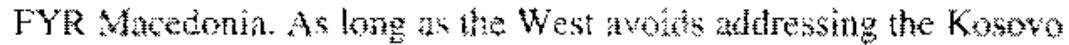
fsue. "ethnic Albutan insurgents in Kowero and in Macelonia are likely to explot the instability in Macedonia for their nationalist agenda." While the tendency in Wostern capitak and in Belgrads

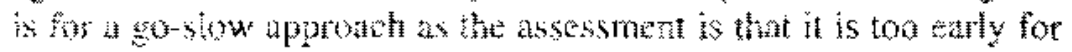
any decision about Kosovos futur pełitical status, Kosovar polfticians insis on independence" These divergences do not proclude the neet tor a proes in tinal status regotiations to begin. The reasons tor this ned inclute the desis by nany in Washongton

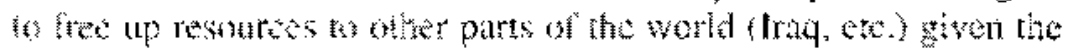

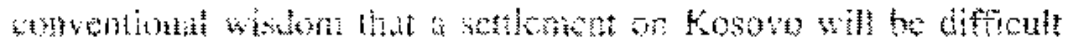
withoul an active US role alse, Kasoro's finat satus is the next order of basiness to UNMIK as mandated by UNSC Restituiton 124. The question of Kosovo's statts chuld come up soon as a

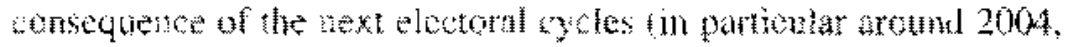
when Kosowo whll hold its secend provinew wide electons and FYROM will hold its presidential electons where status and

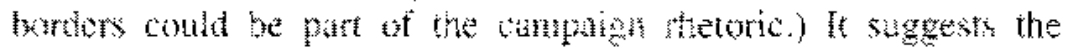

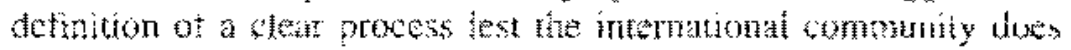
not fill bchind the curve. te. the ned to be protative.

- Whither the falkans whont the Us? How is this viewed in the region? Is the EU able to fill both the security and diplomatic gaps? In ather words, can the European Union "back the Balkans?" ty

The verdict is sth ont. Though, as stated above, the potential for further destabilistion has grenty dimunshet the issues of

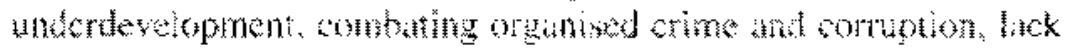

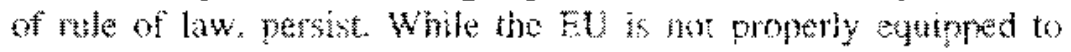

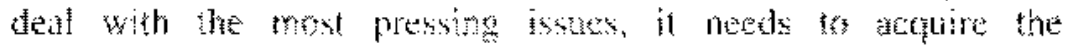
appropriate took if "is is to consididate and build on we

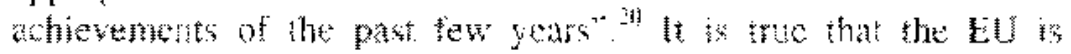

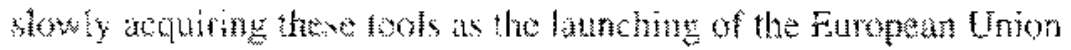

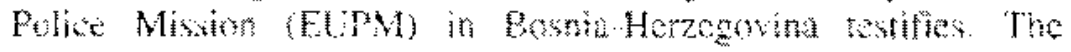

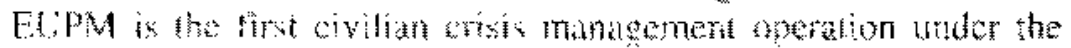

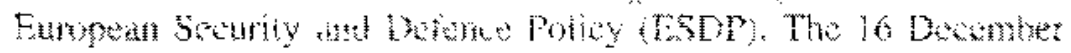

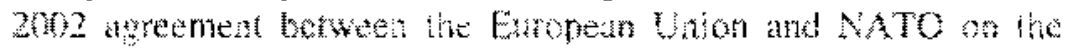

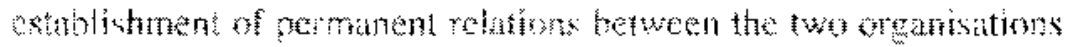

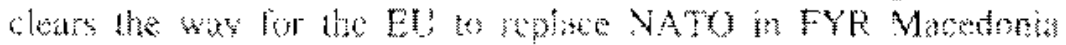


sometime in 2003 and for the Union to explore the possibilities for an EU military role in Bosnia-Herzegovina to replace NATO's SFOR mission at a later date. ${ }^{21}$ The Copenhagen European Council of 12-13 December was clear in this regard. ${ }^{22}$

But, evidently, more is needed by the EU to ensure the region's stability. According to Gerald Knaus and Marcus Knox, three dynamics are at play: "The first is the inevitable but painful adjustment to the end of reconstruction aid, which has kept Bosnia and Kosovo afloat in the post-conflict period. The second is a deepening employment crisis caused by the collapse of the old socialist industries. The third is the growing disenchantment of citizens with the faltering democratic process itself." ${ }^{23}$ In order to cope with these, the EU might need to spread its commitment to economic and social cohesion to the Western Balkans as well. This commitment not only implies a requisite amount of political will (which is lacking) but a restructuring of current Commission structures. ${ }^{24}$

One way to assure its commitment is for greater interventionism in the region. According to Robert Cooper, some sort of post-modern imperialism or "imperialism of neighbours" is necessary. ${ }^{25}$ Though this notion challenges the idea of sovereignty as we know it and could be considered as anathema to the region and its elites, it, nevertheless, merits consideration. After all, this has been the essence of the EU's involvement in the Balkans over the last decade. In Cooper's words, "Instability in your neighbourhood poses threats which no state can ignore. Misgovernment, ethnic violence and crime in the Balkans pose a threat to Europe. The response has been to create something like a voluntary UN protectorate in Bosnia and Kosovo. It is no surprise that in both cases the High Representative is European. Europe provides most of the aid that keeps Bosnia and Kosovo running and most of the soldiers (though the US presence is an indispensable stabilising factor). In a further unprecedented move, the EU has offered unilateral free-market access to all countries of the former Yugoslavia for all products including most agricultural produce. It is not just soldiers that come from the international community; it is police, judges, prison officers, 'central bakers and others. Elections are organised and monitored by the Organisation for Security and Cooperation in Europe (OSCE). Local police..." ${ }^{26}$ There is a case to 


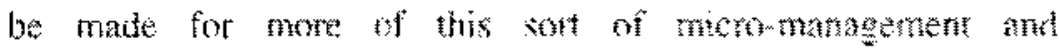
involvement to deat with the uninshed busines un the reging

Another approch stigesested by Alexandros Yandnis and Wim tan Maturs is the need to adopl an eriargenent agenda for South-eastem

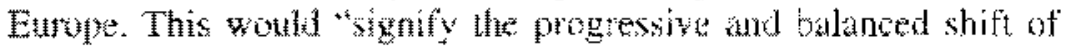

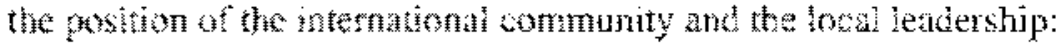

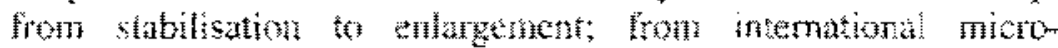

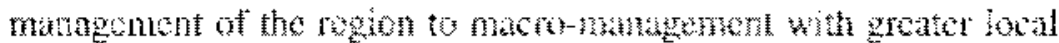

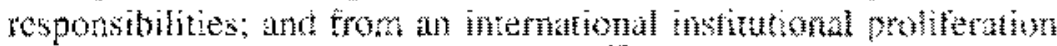
to an integral institutional tratowok."

to is evident from the above that policy propersals as to hod to

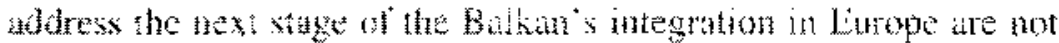
achong.

- Should case-by-case memhershiy serye as the cxample to be followed in the future:

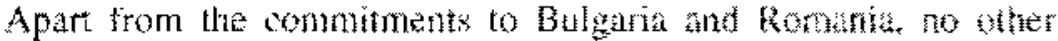

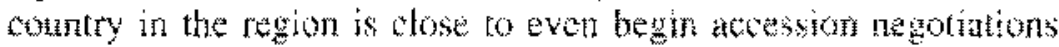

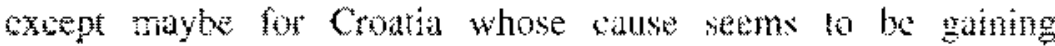

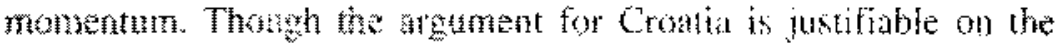

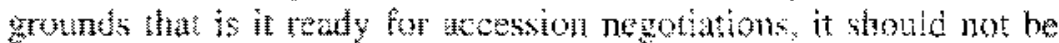

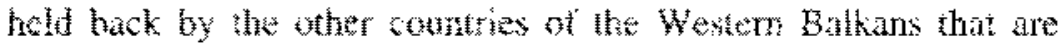

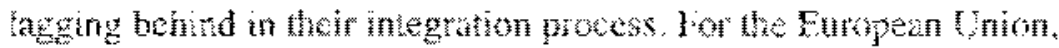

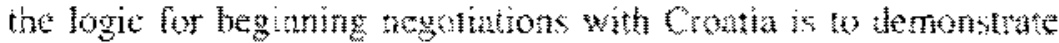
its comritment to enlagement of the regon and that individual

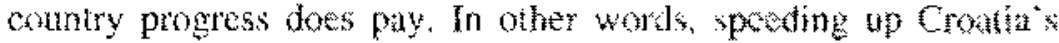
acession might be a powerful positive signal and incentive to the rest that EU mentershila is iery real possibility.

\section{- How to reconele the different speeds?}

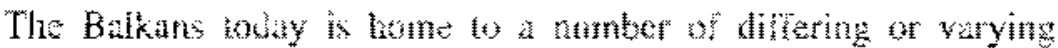

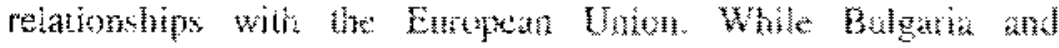

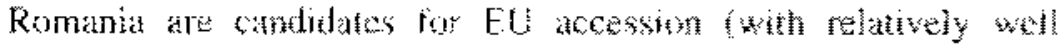

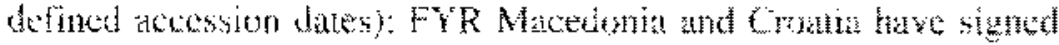
Srabilisation ant Association Agremento SAA Abanta begin negatations with the Commision for an SAA wilie Serbiam

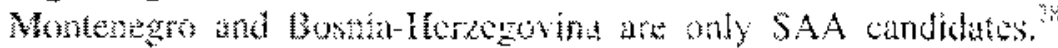


Also the issue of wher Kosovo fits in the EU's future aceession process, in that membership applies to sovereign states, not to territories with undefined status, is silll to be defined. This issue came to the fore recently with the concem of how to proceed with the application of the Stablisation and Association Process (SAP). Likewise for NATO, the same multiple relationships apply with Bulgaria and Romania having been invited to become NATO members in the Prague Summit of November 2002 while Abania, FYR Macedonia, and Croatia are only PfP and EAPC members. Bosnia-Herzegovina and Serbia-Montenegra aspire to join.

\section{Other Issues to be Addressed}

- Are there alternatives to EU membership? EU membership is both a solution ta magnetic pole) and problem (used as an alibi by today's elite).

- Can there be successful democratisation and reform without previously achieving state consolidation?

- Can the local alite be trusted with the implementation of the European project? The lssue of "ownership" is at play here.

- Is there a "Plan B"? Do we need one?

- What impact does the interpretation of developments from the outside have on the region?

- How to reverse the trend of half measures? Has the international community (and the EU in particutar) done as much as it could have done for and in the ragion?

\section{The way forward}

- An integrated EU strategy with the objective of integratitig the countries of South-eastern Europe into the European Union should be the future point of reference. The mitigating factors include tegional instability; lack of adequate and efficient state structures; pending status questions such as the status of Kosovo, Montenegro, and Serbia; organised crime concerns predicated on add-dependent economies; and the consequences of a big bang enlargement on the region given the factor of enlargement fatigue.

Under these conditions, the interplay between the EU and the countries of the region is vital. One crucial element would be to "prioritise the priorities" by demanding key reforms in terns of rule 
of law elcments (courts, judges, legal codes, criminal procedures, etc.) both in the various international community "protectorates" and the sovereign states of the region.

Another factor is the necssity to stress "differentiation" in that EU accession is not perceived regionally but that eath country accedes on its own merit. Though, "differentiarion" via the enlargement process and the Stabilisetion and Associntion Process (SAP) is the approach Brussels is pursuing. the fact is that the stutes of the Western Balkans have yet to be convineed that they are part of the EU's cnlargement strategy. in spite of the Copenhagen Summit declaration..

Finaliy, one guestion that remans hurd 10 answer so 10 what extent the prospect af EU membership hinders or helps the reform process in the countries of SEE suce enlargewent is a moving taryet under which. honce, reforms cannot be anchored, more weatistio formts of linkages need to be definto. For example, this could conde in the form of a reatisto or achievable credibie strategic plan and

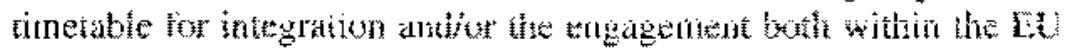
and the national institutions of candidate countries (Bulgarta and Romania), SAP partners (FYROM and Croakia), and the temsining states of the Western Balkans. This will also help explain the need for institutional reform as a priority. In other words, the woidaned of euro-scopticism dte to the longevity of the enlargement process needs to be tackled sooner tather than later.

- The development of functional democracies becmes all the more pressing given the importance of a transfer of responsibilities to the region's elite and the European Lnion as the Lnited States disengages. While there aro more democracies than sovereign states in the Balkans today, political change hat been slow fn coming given the topown nature of the political systems which are elite driven. In other words, in the triptych "state-political societyetwil seciety", the "political society" segment needs to be reformed in order to adders the structural hulc in SEE societes.

In parailel. the way the international community perceives and deals with SEE societies also needs to be addressed. In particutar, the case of the former Yugestav space is telling given that it functions an a series of brokered a drectnents (Dayton, UNSC Resoivtion 1244, the 
Ohrid Agreement, the Belgrade Accord) which have all stopped wars but whose implementation is incomplete as secutity remains precarious for a variety of reasons ranging from the election of nationalst politicians, pending status questions, anachronistic poltical systems, lack of progress in the establishment of rule of law. These factors, in turn. impede the development of functional democracies, which is a sine qua non condition for the stabilisation, and nomalisation of the region.

- The importance of regional cooperation needs to be repeatedly stressed. In view of the fast that "regional ownership" has caught the Imagination both of the region's elite and the European Union, the general sentiment is that solutions to the problems of the region should emanate from the countries of the region. Regional cooperation contributes to the process of regional ownership as it empowers the locals to invest in institutionatised multilateral regional cooperation mechanisms which function in a complementary manner to the European integration process of the Balkan couniries.

The emergence of the South East. European Cooperation Process (SEECP) as the genuine Balkan cooperation process marks a turning point as recognised in a number of General Affairs Councils. The emphasis now is on getting the process in conjunction with the Stabilify Pact to focus on tackling a number of horizontal issues such as the promotion of transport and chergy infrastructure projects, battling organised crime and illicit trafficking, and ensuring the return of refugees and internally displaced persons among others. The principal problem seems to be a lack of sufficieni instruments in assuring that the regional cooperation process is successful and the representation of Kosovo in wiew of the fact that only sovereign states take part in it.

\section{A parting word}

Obviously, all is not gloomy in the region. Regional cooperation is ongoing, especially in the field of major infrasmucture transportation projects, and the democratic process is gradually taking hold. This paper has tried to focus on some of the challenges rather than outline the region's positive trends while acknowledging that these challenges, though serious and pressing are relatively benign to those facing the region and the international community 


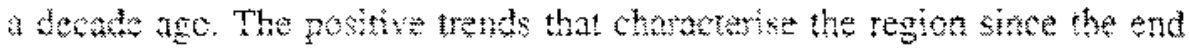
of violent ethai conflus have contributed significantly in this cantut. As a consequence, the Balkans of today might eyen be considered as ratatively "boring" ant inconsequential as the potential of structual detabilisation is protically unimagrinuble. But as the devil lies in the details, it is in the interst of the Eurapean union and the countries of the region to struture the gegion's transition alatuly so hat he integration betomes a teality.

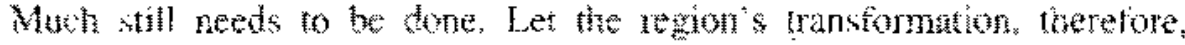
proceret al full steam.

\section{Eudnotes}

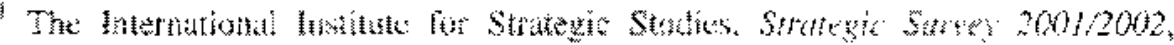

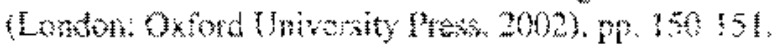

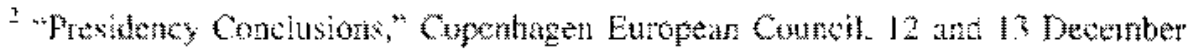
2002 , paragraphs $13-17$.

"Thid, paragraph 23.

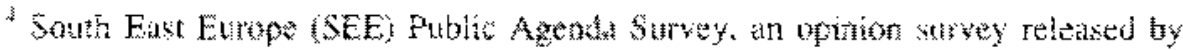

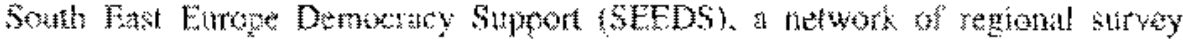

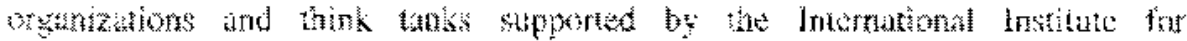

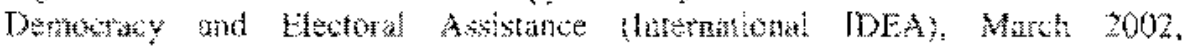

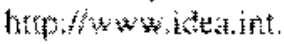

This section draws hervily from Dinitrias Triantapyllot. "Deciphening the

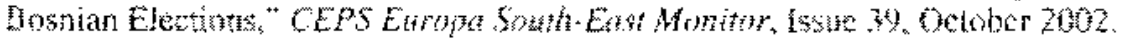

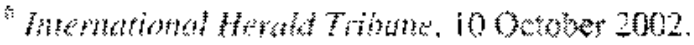

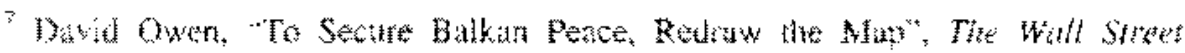

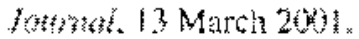

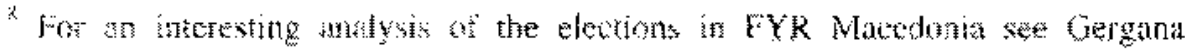

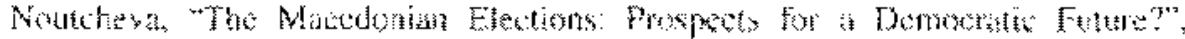

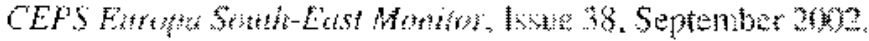

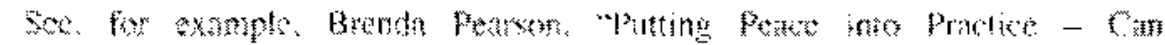

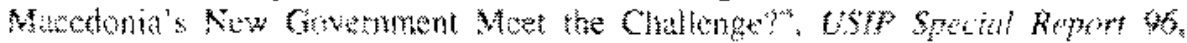

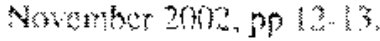

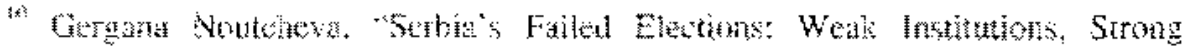

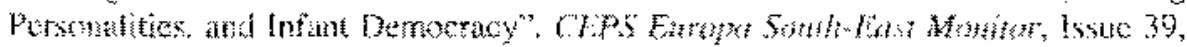
Octotir ans. 
1) Nedjeljko Rudovic, "Montenegrius couut cost of democracy," IWPR's Balkan Crisis Report, No. 393, 23 December 2002.

12 Edmond Harizaj, "Berisha Ditches Cooperation Deal," IWPR's Balkan Crisis Report, No. 397, 13 January 2003.

${ }^{13}$ EU General Affairs and External Relations Council, 21 October 2002.

${ }^{14}$ Edmond Harizaj, "Berisha Ditches Cooperation Deal."

is A new report by the Council ou Foreign Relations calls for the ending of an international military and administrative presence in the Balkans by 2010 provided that a number of conditions are met. These include a curb on organised crime, the ability of refugees to return safely home, and education reform among others. See http:/www.cfr.org/pdf/Balkans_TF.pdf.

${ }^{16}$ See Michael Dziedzic, Laura Rowen, and Phil Williams, "Lawless Rule Versus Rule of Law in the Balkans", USIP Special Report 97, December 2002.

17 Brenda Pearson, "Putting Peace into Practice - Can Macedonia's New Government Meet the Challenge?", p.1.

${ }^{18}$ In a televised interview on 27 December 2002, President Ibrahim Rugova called on the international community to recognize the independence of Kosovo, saying this would contribute to the region's peace and stability.

19 See, for example, Morton Abramowitz and Heather Hurlburt, "Can the EU Hack the Balkans? A Proving Ground for Brussels," Foreign Affairs, September/October 2002, pp. 2-7.

${ }^{20}$ Gerald Knaus and Marcus Knox, "Maintaining Balkan Stability", IWPR's Balkan Crisis Report, No. 383, 18 November 2002.

${ }^{21}$ See remarks by Javier Solana on the start of the European Union Police Mission in Bosnia and Herzegovina, Brussels, 27 December 2002. http:/ue.eu.int/pressdata/EN/declarations/740\$3.pdf.

${ }^{22}$ Presidency Conclusions," Copenhagen European Council, 12 and 13 December 2002, paragraphs 27-30.

${ }^{23}$ Ibid.

24 See Gerald Knaus and Marcus Knox, "Maintaining Balkan Stability". Also see European Stability Initiative, "Western Balkans 2004: Assistance, cohesion and the new boundaries of Europe", 3 November 2002.

${ }^{25}$ Robert Cooper, "The new liberal imperialism", The Observer, 7 April 2002.

${ }^{26}$ Ibid.. 


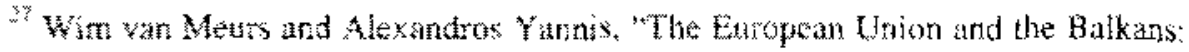

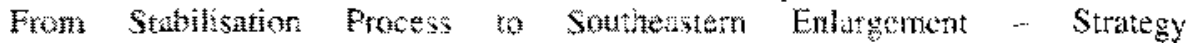

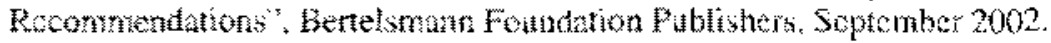

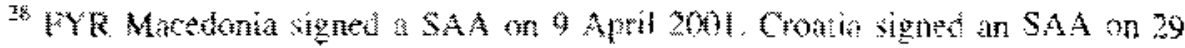
Gerouer 2 but. 